Ks. Wojciech KAMCZYK

(Rybnik)

\title{
PERYKOPA O WSKRZESZENIU LAZARZA (J 11, 1-44) A NAUKA ŚW. AUGUSTYNA O ODPUSZCZENIU GRZECHÓW
}

\begin{abstract}
Augustyn niejednokrotnie w swoim nauczaniu powoływał się na scenę wskrzeszenia Łazarza. Interesujący jest sposób interpretacji tej perykopy, zastosowany przez niego w homiliach. Obraz bowiem wskrzeszenia został ciekawie wykorzystany na użytek duszpasterski, celem pouczenia wiernych o pewnych prawdach wiary. W niniejszym artykule chciałbym podjąć próbę analizy duszpasterskiego nauczania Augustyna, którego podstawą stała się wspomniana perykopa, dotyczącego odpuszczenia grzechów. Artykuł oparty jest przede wszystkim na krótkim 139. jego kazaniu, którego ram zasadniczo nie przekracza ${ }^{1}$ : w całości bowiem dotyczy tematu będącego przedmiotem naszego zainteresowania. Jako uzupełnienie wykorzystana zostanie także homilia 49. na Ewangelię według św. Jana ${ }^{2}$, w której kaznodzieja podjął się również interpretacji tej perykopy, a także kilka z innych homilii, w których nawiązywał do cudu wskrzeszenia Lazarza $^{3}$; pominięte natomiast zostaną inne dzieła Augustyna wspominające tę scenę.
\end{abstract}

\section{SPOSÓB PRZEDSTAWIENIA I INTERPRETACJI PERYKOPY (J 11, 1-44)}

Historia opowiedziana przez ewangelistę Jana niejednokrotnie stawała się przedmiotem nauczania pasterzy Kościoła już w czasach starożytnych. Augustyn miał świadomość, że jest ona dobrze znana słuchaczom, pomimo faktu, iż jej odczytanie poprzedziło jego homilię. Uważał jednak, że tym chętniej chrześcijanie powinni wsłuchać się w jego naukę, skoro tak wielki cud, jak wskrzeszenie Łazarza, opisywany w Ewangelii, znany jest także niewierzą-

\footnotetext{
${ }^{1}$ Por. Sermo 139a, NBA 31/1, 328-332.

${ }^{2}$ Por. In Joannis Evangelium tractatus 49, ed. D.R. Willems, CCL 36, 419-433, thum. J. Szołdrski, PSP 15/2, 29-47.

${ }^{3}$ Por. Sermo 98, NBA 30/2, 200-210; Sermo 126, NBA 31/1, 110-128; Sermo 128, NBA 31/1, 150-166; Sermo 295, NBA 33, 310-320.
} 
$\mathrm{cym}^{4}$. By lepiej przybliżyć naukę, wyprowadzaną z tego ewangelicznego fragmentu, Augustyn osadził perykopę o Łazarzu w szerszym kontekście:

„W świętej Ewangelii słyszymy o trzech zmarłych wskrzeszonych przez Pana Jezusa. Pierwsza, córka przełożonego synagogi, do którego domu przybył i wskrzesił ją z martwych, choć zawezwany był do zagrożonej choroba, powiedział jej: «Dziewczynko, tobie mówię, wstań», i wskrzesił ją. Kolejny, młodzieniec, który już poza bramy miasta był wynoszony i gorzko opłakiwany przez owdowiałą matkę; gdy go więc zobaczył, kazał stanąc niosącym i rzekł: «Młodzieńcze, tobie mówię, wstań; i usiadł ów zmarły i zaczął mówić i oddał go jego matce». Trzecim jest ów Łazarz, którego widzimy oczami wiary i umarłego i wskrzeszonego, jeszcze większym cudem, wielkim błogosławieństwem; był bowiem czterodniowym trupem i już cuchnął; i on jednak został wskrzeszony"s.

Cudowne wydarzenie wskrzeszenia Łazarza z Betanii Augustyn osadził, jak widać, w kontekście pozostałych wskrzeszeń dokonanych przez Jezusa, opisanych na kartach Ewangelii. Przytaczając każde z tych wydarzeń Kaznodzieja podjął próbę ich usystematyzowania, podporządkowując ich przedstawienie celom swojej interpretacji.

$\mathrm{Na}$ pierwszym miejscu umieścił cud wskrzeszenia córki przełożonego synagogi z Kafarnaum, opisany w Ewangelii według św. Marka (5, 35-43). Widział w tym wydarzeniu cud najprostszy: początkowo, w zamierzeniu proszącego ojca, Jezus nie był wzywany do zmarłej, ale do chorej dziewczynki. Sama śmierć nastąpiła niedawno, ledwie przed chwilą. Ciało zmarłej pozostawało w domu, na łóżku. Nie została jeszcze wyniesiona na zewnątrz. Na słowa Jezusa: „Dziewczynko, tobie mówię, wstań!”, zmarła powróciła do życia6

${ }^{4}$ Por. Sermo 139a, 1, NBA 31/1, 328.

${ }^{5}$ Tamże 139a, 2, NBA 31/1, 328: „A Domino Iesu Christo in sancto Evangelio tres mortuos didicimus suscitatos. Unam, filiam archisynagogi, ad cuius domum venit, et eam, cum prius periclitari aegritudine audisset, mortuam invenit; et ait illi: «Puella, tibi dico, surge» (Mc 5, 41), et resurrexit. Alium, iuvenem, qui iam extra portam civitatis mortuus efferebatur, et graviter a matre vidua plangebatur; tunc enim vidit haec, sed iussit stare portantes, et ait: «Iuvenis, tibi dico, surge; et sedit ille mortuus, et coepit loqui, et reddidit illum matri suae» (Lc 7, 14-15). Tertius est iste Lazarus, quem modo fidei oculis vidimus et morientem et resurgentem, valde maiori miraculo, et grandi beneficio; erat enim quadriduanus, et iam putebat; resuscitatus est tamen". Tłumaczenia tekstów Augustyna, jesli nie zaznaczono inaczej, pochodzą od autora artykułu.

${ }^{6}$ Por. Sermo 98, 4, NBA 30/2, 204: „Resuscitavit filiam mortuam Archisynagogi, ad quam aegrotantem petebatur, ut eam de aegritudine liberaret. Et cum pergit, mortua nuntiatur; et quasi iam frustra fatigaretur, renuntiatum est patri eius: «Puella mortua est, quid adhuc fatigas Magistrum?» (Mc 5, 35). Ille autem perrexit, et ait patri puellae: Noli timere, «tantummodo crede» (Mc 5, 36). Venit ad domum, et invenit iam obsequia funeri debita praeparata: et dicit illis: «Nolite flere, non enim est mortua puella, sed dormit» (Mc 5, 39). Verum dixit: dormiebat, sed illi a quo poterat excitari. Hanc excitans, reddidit vivam parentibus”; Sermo 128, 12, 14, NBA 31/1, 166: „Suscitavit Christus mortuam in domo filiam Archisynagogi (Mc 5, 22-42). In domo erat, elata nondum erat". 
Na drugim miejscu kaznodzieja usytuował cud wskrzeszenia młodzieńca, syna owdowiałej matki, gorzko przez nią opłakiwanego (Łk 7, 11-17). Owo zdarzenie ma miejsce u bram miasta, $\mathrm{w}$ trakcie wynoszenia ciała zmarłego w celu pogrzebania. Augustyn zwrócił uwagę, że i w tym przypadku cud nastapił na słowa Jezusa, skierowane do zmarłego. Zmarły usiadł, zaczął mówić, a Jezus zwrócił go jego matce, co może sugerować dostrzeżenie pewnej celowości dokonanego wskrzeszenia. Augustyn wyraził się dosłownie, że Jezus „oddał" (reddidit), zwrócił młodzieńca matce?.

Trzecim w kolejności jest cud wskrzeszenia Łazarza (J 11, 1-44). To jemu kaznodzieja poświęcił najwięcej miejsca. Ten cud także uznał za najważniejszy, związany z największym błogosławieństwem. Łazarz został już pochowany, od czterech dni spoczywał w grobie zamkniętym sporym kamieniem, owinięty w płótna, jego ciało podległe rozkładowi cuchnęło. Te wszystkie okoliczności nie stanęły jednak na drodze Jezusowi, który przybywszy do Betanii wskrzesił również Łazarza ${ }^{8}$. Świadkiem całego zdarzenia są uczniowie, którzy towarzyszą Jezusowi i biorą udział w całym zajściu zostając nie tylko biernymi świadkami wskrzeszenia, ale współdziałając z Jezusem9 9

Przedstawiając te trzy wskrzeszenia i zestawiając je ze sobą pasterz wiernych Hippony nakreślił ,teorię” interpretacji powyższych zdarzeń:

„Co więc oznaczają te trzy śmierci? Nie są one bez znaczenia i cudowne czyny Pana są tajemniczymi naukami"10.

A w innym miejscu rozszerzył swoją myśl:

„Dowiadujemy się o trzech zmarłych wskrzeszonych widzialnie przez Chrystusa, o tysiącach - niewidzialnie. Któż wie jednak, ilu zmarłych wskrzesił Chrystus widzialnie? Nie wszystko bowiem, co uczynił zostało spisane. Jan mówi: «Wiele innych rzeczy uczynił Jezus, które gdyby je spisać, jak sądzę, to cały świat nie mógłby pomieścić ksiąg». I dlatego bez wątpienia

${ }^{7}$ Por. tamże 98, 4, NBA 30/2, 204: „Excitavit et hunc iuvenem viduae filium, de quo nunc admoniti sumus, ut hinc ista quae ipse largiri dignatur, cum vestra Caritate loqueremur. Modo audistis quomodo excitatus est (por. Lc 7, 12nn). Appropinquabat Dominus civitati; et ecce efferebatur mortuus iam extra portam. Misericordia commotus, quod flebat mater vidua et destituta unico filio, fecit quod audistis, dicens: "Adolescens, tibi dico, surge. Surrexit ille mortuus, coepit loqui; et reddidit illum matri suae» (Lc 7, 14-15)”; Sermo 128, 12, 14, NBA 31/1, 166: „Sed et iuvenem filium viduae suscitavit Dominus, quando extra portam civitatis mortuus efferebatur".

${ }^{8}$ Por. Sermo 98, 4, NBA 30/2, 204: „Excitavit et Lazarum de sepulcro”; Sermo 128, 12, 14 , NBA 31/1, 166: ,Sed et hic mihi tertius mortuus est, qui etiam perductus est ad sepulcrum. Iam supra se habet consuetudinis pondus, moles eum terrena multum premit. Multum enim exercitatus est in flagitiis, consuetudine sua nimia praegravatur. Clamat et Christus: Lazare, prodi foras!”.

${ }^{9}$ Por. Sermo 98, 6, NBA 30/2, 208: „Videte genus resuscitationis. Processit de monumento vivus, et ambulare non poterat. Et Dominus ad discipulos: «Solvite eum, et sinite abire» (J 11, 44)".

${ }^{10}$ Sermo 139a, 2, NBA 31/1, 328: „Quid sibi volunt isti tres mortui? Non enim nihil significant, et Domini facta miraculorum, verba sunt mysteriorum". 
było wielu innych wskrzeszonych, ale nie na próżno tylko trzech jest wzmiankowanych. Pan nasz Jezus Chrystus pragnął, aby duchowo rozumiano to, co czynił dla ciała. Ani też nie czynił cudów, ale tak, aby to, co czynił, wzbudzało podziw u widzących, a prawdziwe poznanie u rozumiejących"11.

Augustyn miał świadomość, że Chrystus żyjąc pośród ludzi nieustannie ich nauczał. Czynił to nie tylko samymi swoimi słowami, ale także poprzez swoje czyny dawał ludziom konkretne przykłady, wskazania i nauki. Takie też znaczenie, symboliczne, a wręcz duchowe i mistyczne, mają trzy cuda przywrócenia zmarłych do życia. Z takiego sposobu wyjaśniania Pisma Świętego korzystał święty z Tagasty dość często, zwłaszcza głosząc homilie kierowane do wiernych Afryki Północnej, popierając swą interpretację innymi tekstami biblijnymi ${ }^{12}$. Za takim sposobem interpretacji przemawia także fakt, iż w ewangeliach opisane zostały zaledwie trzy wskrzeszenia z martwych, a Jezus dokonał zapewne wiele takich cudów. Samo Pismo Święte zaświadcza o tym, że nie wszystkie cuda dokonane przez Jezusa zostały spisane (por. J 21, 25). Wolą samego Jezusa było duchowe rozumienie dzieł, których dokonywał. Nie czynił ich dla podziwu, ale ku lepszemu rozumieniu poznających i wierzących.

Kaznodzieja z Hippony próbował wskazać na powiązanie trzech wskrzeszeń dokonanych przez Jezusa. Wyraźnie sugerował gradację owych niezwykłych wydarzeń ze zmarłymi ${ }^{13}$. Tak uporządkowane wydarzenia stały się podstawą wyciagnięcia moralnej nauki, której sens należało wydobyć nie z pojedynczego czynu, ale z wielu zestawionych ze sobą znaków:

„Trzy rodzaje śmierci odkrywamy w grzechach człowieka. Odkryjcie te trzy śmierci. Pierwszą była owa dziewczynka umarła w domu, nie była jeszcze wyniesiona; ów zaś młodzieniec już był wyniesiony poza bramę; Łazarz zaś już pochowany i za zatoczonym kamieniem skalnym"14.

Trzy rodzaje cielesnej śmierci, opisanej w Ewangeliach, stały się symbolem duchowej śmierci, za którą nasz Kaznodzieja uznał grzech. W cytowanej

${ }^{11}$ Sermo 98, 3, NBA 30/2, 202: „Tres autem mortuos invenimus a Domino resuscitatos visibiliter, millia invisibiliter. Quot autem mortuos visibiliter suscitaverit, quis novit? Non enim omnia quae fecit scripta sunt: Ioannes hoc dicit:«Multa alia fecit Iesus, quae si scripta essent, arbitror totum mundum non posse libros capere» $(\mathrm{J} 21,25)$. Multi ergo sunt alii sine dubio suscitati: sed non frustra tres commemorati. Dominus enim noster Iesus Christus ea quae faciebat corporaliter, etiam spiritaliter volebat intellegi. Neque enim tantum miracula propter miracula faciebat: sed ut illa quae faciebat, mira essent videntibus, vera essent intellegentibus", tłum. M. Starowieyski, OŻ 3, Kraków 1984, 181-182.

${ }^{12}$ Por. M. Simonetti, Między dostownościq a alegoria, thum. T. Skibiński, Kraków 2000, 350.

${ }^{13}$ Por. M. Pontet, L'exégèse de S. Augustin prédicateur, Paris 1945, 567.

${ }^{14}$ Sermo 139a, 2, NBA 31/1, 328: „Invenimus ergo in peccatis hominum mortis genera tria. Recolite istos tres mortuos; primo illa puella in domo mortua erat, nondum elata erat; iuvenis autem ille, iam elatus extra portam; Lazarus autem sepultus, et mole lapidis pressus". 
homilii nie zostało sprecyzowane, o jak poważne grzechy chodzi. Sądząc jednak z porównania tych grzechów do śmierci fizycznej, można przypuszczać, że Biskupowi Hippony chodziło o te grzechy, które w innym miejscu określał śmiertelnymi (peccata mortifera) $)^{15}$.

Fakt interpretacji cielesnej i fizycznej śmierci w znaczeniu duchowym, jako grzechu także jest charakterystyczny dla Augustyna. Mając przed oczami wzór św. Pawła (por. 1Kor 3, 1-3), stara się wyjaśniać cielesne obrazy na sposób duchowy, uznając, że obraz cielesny łatwiej przemawia do tych, którzy są jeszcze czymś cielesnym i pomoże im w zrozumieniu tajemnic duchowych; łatwiej jest bowiem przejść od rozumienia tego co cielesne, do tego co duchowe ${ }^{16}$.

Wskazując jednak na różnice pomiędzy zmarłymi, a w zasadzie na różnice dotyczące losów ciała zmarłego oraz drogę, jaką przechodzi po śmierci do momentu ,spotkania” z Jezusem, wyprowadził naukę o różnej sytuacji grzesznika. Ciało zmarłej dziewczynki pozostawało jeszcze w domu, nie było wynoszone, kiedy wskrzesił ją Jezus. To aluzja do grzechu popełnianego „w sercu”, jedynie decyzją woli, przyzwoleniem na zło ${ }^{17}$. Młodzieniec znajdował się już przy bramie miasta, trwał jego pogrzeb, kiedy zainterweniował Jezus. Jest to symbol grzechu, który po zapadnięciu decyzji przeszedł w fazę czynu, został dokonany i uzewnętrznił się ${ }^{18}$. Natomiast przypadek Łazarza zdaje się być najcięższym, gdyż nie tylko był już pochowany, ale również zatoczony został nad nim kamień skalny i rozpoczął się rozkład jego ciała, którego skutkiem była nieprzyjemna woń ${ }^{19}$. To sytuacja człowieka, który przyzwyczaił się do grzechu, a nawet popadł w nałóg ${ }^{20}$.

Dwa pierwsze ze wspominanych wskrzeszeń posłużyły naszemu Kaznodziei do nauczania o grzechu, nie tyle określając jego „ciężkość”, ile raczej drogę, jaką czyni w samym człowieku, pewien stopień zaawansowania. I jeden i drugi zdają się być jedynie chwilowym ustąpieniem pokusie, stąd choć

15 Por. A.G. Fitzgerald, Pénitence, tłum. C. Broc, w: Encyclopédie Saint Augustin. La Méditerranée et l'Europe $I V^{e}-X X I^{e}$ siècle, ed. A.D. Fitzgerald, Paris 2005, 1118. Za śmiertelne uznał Augustyn trzy kategorie grzechu: zabójstwo, świętokradztwo i cudzołóstwo, zob. Sermo 352, 3, 8, NBA 34, 218: „Grave vulnus est: adulterium forte commissum est, forte homicidium, forte aliquod sacrilegium, gravis res, grave vulnus, lethale, mortiferum: sed omnipotens medicus"; por. A.M. La Bonnardière, Pénitence et reconciliation des pénitents d'après saint Augustin, REAug 13 (1967) 256. Podobna sugestia wynika z analizy M. Pontet (L'exégèse de S. Augustin, s. 567).

${ }^{16}$ Por. Sermo 23, 3-4, NBA 29, 438-440; Simonetti, Między dostownościq a alegoriq, s. 350-351.

${ }^{17}$ Por. Sermo 139a, 2, NBA 31/1, 328-330; Fitzgerald, Pénitence, s. 1118.

${ }^{18}$ Por. Sermo 139a, 2, NBA 31/1, 330: „Si autem faciat quod decrevit, processit mors, iam foris est; sed et ipsa paenitendo finitur, et mortuus elatus vitae redditur"; Sermo 128, 12, 14, NBA 31/1, 166: „Si autem perfeceris, iam foras elatus es, sed habes qui tibi dicat: «Iuvenis, tibi dico, surge!» (Lc 7, 15)".

${ }^{19}$ Por. Pontet, L'exégèse de S. Augustin, s. 567-568.

${ }^{20}$ Por. Sermo 139a, 2, NBA 31/1, 330: „Si autem facto accedat etiam consuetudo, iam putet, et tamquam lapide mole ipsius consuetudinis premitur". 
stanowią poważną winę, dość łatwo można jednak dostąpić „wskrzeszenia”21. Sytuacja przyzwyczajenia do grzechu, której obrazem jest cud wskrzeszenia Łazarza, jest o wiele trudniejsza do pokonania, ale i w tym wypadku nie jest to niemożliwe.

\section{MISTYCZNA NAUKA JEZUSA O ODPUSZCZENIU GRZECHÓW}

Trzy rodzaje wskrzeszeń nie służą Augustynowi jedynie do ukazania moralnego trzech rodzajów grzechów, ale także do tego, by wskazać drogę do wyzwolenia się z nich.

1. „Wskrzeszająca” moc Chrystusa. Dostrzegając złe położenie tego, kto popadł w nałóg grzechu, Augustyn wskazuje na działanie Jezusa:

„On, którego głos do serca przenika, woła: «Łazarzu, wyjdź na zewnątrz», to jest: Żyj, wyjdź z grobu, zmień życie, skończ śmierć"22.

Chrystus jest tym, który wzywa, a więc także obdarza życiem, On sam wyzwala ze śmierci; to na Jego słowa następuje powstanie z martwych. W opisie wskrzeszenia córki Jaira Jezus zwraca się do dziewczynki słowami: „Dziewczynko, mówię ci, wstań! (Mk 5, 41)"23. Kiedy spotyka orszak pogrzebowy syna wdowy z Nain, zatrzymuje niosących ciało i zwraca się do młodzieńca: „Młodzieńcze, tobie mówię, wstań! (Łk 7, 14)”24. W ostatniej perykopie, Jezus woła w kierunku grobu: „Łazarzu, wyjdź na zewnątrz! (J 11, 43)”25. To wołanie było dla Augustyna symbolem działania łaski, obecnej w człowieku ochrzczonym ${ }^{26}$ :

„Z jaką trudnością [Łazarz] wstaje, jak gnębi go ciężar złego nałogu! Jednakże wstaje. Ukryta wewnątrz łaska się ożywia; wstaje na głośne wezwanie"27.

Słowa Kaznodziei były przestrogac, przed pozostawaniem w grzechu i przyzwyczajaniem się do niego, a jednocześnie dodawały nadziei na wyrwanie się z grzesznych przyzwyczajeń. Dzięki wezwaniu Chrystusa ożywia

${ }^{21}$ Por. Sermo 98, 6, NBA 30/2, 208: „Sive iam quod cogitavit admisit; nec sic desperetur. Non surrexit mortuus intus, surgat elatus. Poeniteat facti, de proximo reviviscat: non eat in profundum sepulturae, non accipiat desuper consuetudinis molem".

${ }^{22}$ Sermo 139a, 2, NBA 31/1, 330: „Ille, ille, cuius vox ad cor pervenit, clamet: «Lazare, veni foras»; id est: Vive, exi de sepulchro, muta vitam, fini mortem".

${ }^{23}$ Por. Sermo 139a, 2, NBA 31/1, 328.

${ }^{24}$ Por. Sermo 139a, 2, NBA 31/1, 328.

${ }^{25}$ Por. Sermo 139a, 2, NBA 31/1, 330; Sermo 128, 12, 14, NBA 31/1, 166.

${ }^{26}$ Por. In Joannis Evangelium tractatus 49, 24, CCL 36, 431: „Sed ut confitearis, Deus facit magna voce clamando, id est, magna gratia vocando".

${ }^{27}$ Tamże: „Quam difficile surgit, quem moles malae consuetudinis premit! Sed tamen surgit: occulta gratia intus vivificatur; surgit post vocem magnam”, PSP 15/2, 44. 
się ukryta wewnątrz grzesznika łaska. Zapewne jest to aluzja do łaski otrzymywanej przez każdego chrześcijanina w momencie chrztu. Obrzęd bowiem pojednania sprawia, że dzięki mocy Jezusa, której symbolem w tej perykopie stało się wezwanie, łaska na nowo odżywa w człowieku ${ }^{28}$. Już wcześniej była ona w człowieku, który popadł w grzechy, teraz zaś odżywa na nowo:

„Woła i Chrystus: «Łazarzu, wyjdź na zewnątrz!» Człowiek bowiem najgorszego nałogu już cuchnie. Słusznie tam Chrystus wołał; i nie tylko wołał, lecz „donośnym głosem wołał». Bowiem na wołanie Chrystusa także tacy, chociażby umarli, chociażby pogrzebani, chociażby śmierdzący, wskrzeszeni zostają jednak i tacy; zmartwychwstają. O nikim bowiem spoczywającym nie trzeba tracić nadziei przed takim Ożywicielem"29.

Dla Chrystusa jako ożywiciela, sprawcy zmartwychwstania umarłych, nie ma sytuacji, której nie mógłby zmienić, nie ma takiej duchowej śmierci, z której nie potrafiłby wskrzesić. Ci zaś, którzy znajdują się w najtrudniejszej nawet sytuacji, skrępowani nałogami, nie powinni tracić nadziei na Boże przebaczenie; w ten sposób podkreślił Augustyn Bożą wszechmoc, w działaniu zaś Chrystusa widział działanie samego Boga Ojca:

„Nie czyni czego innego Ojciec, a czego innego Syn, ponieważ wszystko, co czyni Ojciec, czyni przez Syna. Wskrzesił Łazarza Syn, czyż nie wskrzesił go Ojciec?"'30

Działanie Boga Ojca i działanie Syna są tożsame. W gruncie rzeczy przez Jezusa Chrystusa wskrzesza Bóg Ojciec. Jezus nie czynił nic innego niż to, czego pragnął Ojciec. Wszystko zatem, czego dokonał, jest dziełem samego Ojca. Każde wskrzeszenie, a więc również każde dzieło odpuszczenia grzechów, nawet człowieka najbardziej nimi związanego, jest także dziełem Ojca.

${ }^{28}$ Por. tamże: „Quomodo processit ligatis pedibus miraris, et non miraris quia surrexit quatriduanus? In utroque potentia Domini erat, non vires mortui. Processit, et adhuc ligatus est: adhuc involutus, tamen iam foras processit. Quid significat? Quando contemnis, mortuus iaces; et si tanta quanta dixi contemnis, sepultus iaces: quando confiteris, procedis. Quid est enim procedere, nisi $\mathrm{ab}$ occultis velut exeundo manifestari? Sed ut confitearis, Deus facit magna voce clamando, id est, magna gratia vocando. Ideo cum processisset mortuus adhuc ligatus, confitens et adhuc reus; ut solverentur peccata eius, ministris hoc dixit Dominus: «Solvite illum, et sinite abire» (J 11, 44). Quid est: «Solvite, et sinite abire»? «Quae solveritis in terra, soluta erunt et in coelo» (Mt 15, 18)", PSP $15 / 2,45$.

${ }^{29}$ Sermo 128, 12, 14, NBA 31/1, 166: „Clamat et Christus: «Lazare, prodi foras!» Homo enim pessimae consuetudinis iam putet. Merito ibi Christus clamavit; nec solum clamavit, sed «magna voce clamavit (cf. J 11, 14-44)». Ad Christi enim clamorem etiam tales, licet mortui, licet sepulti, licet putentes, resurgent tamen et ipsi; resurgent. De nullo enim iacente desperandum est sub tali suscitatore".

${ }^{30}$ Sermo 126, 8, 10, NBA 31/1, 122: „Non alia Pater facit, alia Filius facit, quia omnia quae Pater facit, per Filium facit. Suscitavit Lazarum Filus (cf. J 11), numquid eum Pater non suscitavit?”. 
2. Postawy grzesznika. Choć zmarli wskrzeszani przez Jezusa nie moga podjąć żadnych działań zmierzających do ich wskrzeszenia, to jednak Augustyn, mówiąc o wskrzeszeniu duchowym wskazuje na postawy, jakie wobec działania Jezusa powinni przyjmować grzesznicy. Czyni to już w momencie nawiązania do wskrzeszenia córki Jaira:

„Jeśli ktoś ze złego pragnienia w sercu się zgadza, i to postanawia wprowadzić w czyn, do czego został zwabiony, już jest umarły. Nikt nie wie, ponieważ nie jest wyniesiony; śmierć jest sekretną, w domu jest, w izdebce jest, ale jednak jest śmieré"sil.

Obraz wskrzeszenia dziewczynki, w jej własnym domu, symbolizował dla Augustyna grzech popełniony w sercu, samym pragnieniem, zgodę na grzech w sercu. Używając określeń ,,śmierć sekretna”, „w domu”, „w izdebce”, Kaznodzieja nasz odniósł grzech nie tyle do jego uzewnętrznienia, ale do samych intencji popełniającego. Jest to więc grzech wewnętrzny, dokonywany „W sercu" 32 .

Wystarczającym było samo postanowienie wprowadzenia grzechu w czyn, ono już miało być uważane za grzech, choć faktycznie owo zamierzenie nie zostało zrealizowane. O owym grzechu nikt na zewnątrz nie wiedział, bo nie został „wyniesiony na zewnątrz”, podobnie jak ciało zmarłej dziewczynki. Nie zawsze także i sam grzesznik był w stanie go sobie uświadomić. Uprzedzając zaś ewentualnych oponentów takiej nauki, Kaznodzieja argumentował:

„Niech nikt sobie nie mówi: nie popełniłem cudzołóstwa, jeśli postanowił popełnić; jeśli zgodził się uczynić pokusę przyjemnościa, już popełnił: on cudzołożnik, ona czysta. Zwróć się do Boga, niech ci odpowie o owej śmierci w domu, o śmierci wewnętrznej, o śmierci w izdebce; o jakich łożach czytamy: «Co mówicie w waszych sercach i na łożach waszych rozważajcie». Posłuchaj więc zdania wskrzesiciela o owej śmierci: «Kto spojrzy - rzecze - na kobietę z pożądliwością, już dopuścił się z nią cudzołóstwa w swoim sercu», choć jeszcze nie popełnił cudzołóstwa swoim ciałem"»33.

${ }^{31}$ Sermo 139a, 2, NBA 31/1, 328-330: „Si quisquam malae concupiscentiae in corde consenserit, et quod illa blandiendo suaserit, facere decreverit, iam mortuus est. Nemo scit, quia non est elatus; secreta mors est, in domo est, in cubiculo est, tamen mors est".

32 Por. Sermo 98, 7, NBA 30/2, 208: „Sive adhuc peccatum in corde conceptum est, et non processit in factum; poeniteat, corrigatur cogitatio, surgat mortuus intra domum conscientiae"; por. Pontet, L 'exégèse de S. Augustin, s. 567.

${ }^{33}$ Sermo 139a, 2, NBA 31/1, 330: „Nemo se dicat non fecisse adulterium, si facere statuit; si titillanti delectationi faciendum esse consenserit, iam fecit; ille adulter, illa casta est. Deum interroga; respondeat tibi de morte ista domestica, de morte interiore, de morte cubiculari; de qualibus cubilibus legimus: «Quae dicitis in cordibus vestris, et in cubilibus vestris compungimini» (Ps 4, 5). Audi ergo de ista morte resuscitatoris sententiam: «Qui viderit, inquit, mulierem ad concupiscendum eam, iam moechatus est eam in corde suo» (Mt 5, 28), qui nondum exercuit fornicationem in corpore suo". 
Wśród chrześcijan Hippony za złe uznawano prawdopodobnie raczej tylko to, co było czynem, a nie same złe myśli, czy zamierzenia. Tymczasem każdy, kto dotykająca go pokusę zmienia w przyjemną myśl i zamierzenie, już zaciąga winę. Kaznodzieja nasz przypomina, powołując się na zdanie z Ewangelii według św. Mateusza (por. Mt 5, 28), że sam Chrytusus nauczał, że grzech popełnia niekoniecznie tylko ten, kto się go zewnętrznie dopuszcza, ale wystarczy zapragnąć zła w sercu i już wtedy zaciąga się winę. Grzechem jest już sama decyzja popełnienia określonego czynu. Wtedy jednak grzeszy jedynie ten, kogo dotyczy zamierzenie, a nie popełnia grzechu nikt inny, na przykład obiekt jego pożądania ${ }^{34}$. Uzasadniając swoje nauczanie Biskup Hippony powołuje się także na fragment psalmu, który mówi o rozważaniu czynów człowieka w sercu i na łożach, co dosłownie odnosi się do obrazu zmarłej dziewczynki, leżącej jeszcze w swoim łóżku.

Pierwszym aktem samego grzesznika powinno być uznanie grzechu w sobie. To zapewne było celem przypomnienia tej kwestii przez Augustyna, by uświadomić wiernym istotę grzechu, jako zgody na zło w człowieku. W podobny sposób wyjaśnia Augustyn konieczność świadomości grzechu, tłumacząc symbolikę kamienia zakrywającego grób zmarłego Łazarza: oznacza on, jak to zostało wspomniane wcześniej, przyzwyczajenie, któremu uległ grzesznik:

„Kto więc przyzwyczajeniem jest przygnieciony, jest bierny wobec siły”35.

Kamień, skała, które zamykają grób Łazarza, są pewnym ciężarem, który przygniata grzesznika. Sam o własnych siłach nie jest on w stanie go podnieść, sam nie jest w stanie wyjść z grobu. Jest to jakby dodatkowe obciążenie, na które Augustyn zwraca uwagę. Jest to swoista trudność związana ze zmianą postępowania, ale konieczne jest także jeszcze inne działanie uzdrawiające, które ma pomóc zmienić nie tylko sam zły czyn, lecz również samo przyzwyczajenie, które należy usunąć, tak jak usuwa się kamień, skałę zakrywającą wejście do grobu:

„Każdemu człowiekowi, którego gnębi zły nałóg, mówi się: «Przyszedł do grobu». A była to pieczara i kamień był na niej położony. Zmarły jest pod kamieniem, grzesznik pod prawem. Wiecie bowiem, iż prawo dane Żydom, wypisane było na kamieniu. Wszyscy zaś grzesznicy są pod prawem, a i ci, którzy dobrze żyja, są z prawem: «Prawo nie jest ustanowione dla sprawiedliwego»" ${ }^{\prime 36}$.

${ }^{34}$ Por. Pontet, L'exégèse de S. Augustin, s. 567.

${ }_{35}$ Sermo 139a, 2, NBA 31/1, 330: „Qui ergo consuetudine premuntur, vim patiuntur”.

${ }^{36}$ In Joannis Evangelium tractatus 49, 22, CCL 36, 430: „Omni homini dicitur, qui premitur pessima consuetudine: «Venit ad monumentum. Erat autem spelunca, et lapis superpositus erat ei» (J 11, 38). Mortuus sub lapide, reus sub lege. Scitis enim quia Lex quae data est Iudaeis, in lapide scripta est (cfr. Gn 31,18). Omnes autem rei sub lege sunt: bene viventes cum lege sunt. «Iusto lex posita non est» (1Tim 1, 9)", PSP 15/2, 44. 
Innym możliwym wyjaśnieniem znaczenia samego kamienia jest przyrównanie go do prawa moralnego, które obowiązuje człowieka. Augustyn na myśli ma przede wszystkim dziesięć przykazań Bożych, gdyż mówi o prawie wypisanym na kamieniu, co wyraźnie odnosi się do kamiennych tablic z dekalogiem, otrzymanych przez Mojżesza (por. Pwt 5, 22).

Prawo ustanowione było dla ludzi grzesznych, by mogli rozróżnić dobro od zła. Dla grzesznika prawo jest tym, co krępuje, przygniata, ciąży i uniemożliwia swobodę. Człowiek sprawiedliwy jest ,z prawem”, współdziała z nim, współpracuje, ono go nie ogranicza. Kaznodzieja sugeruje zatem, że „zmarły” powinien zmienić swoje przyzwyczajenie także w sensie podchodzenia do prawa, które dotąd jakby go ograniczało, zniewalało, było dla niego ciężarem. Stając się sprawiedliwym winien zaczać z prawem współpracować, być obok niego, można powiedzieć, żyć wraz z nim. Kiedy już nastąpi u niego uświadomienie sobie zła i grzechu, oraz właściwe zrozumienie postaw moralnych, wtedy nasz Kaznodzieja podsuwa mu kolejne zalecenie:

„Lecz kiedy spojrzy Pan, żałuje decyzji, żałuje wyrażenia zgody, w izdebce umarl, w izdebce zostaje wskrzeszony" ${ }^{\prime 3}$.

Pod wpływem działania Jezusa i uświadomienia sobie zła, grzesznik powinien sobie wzbudzić żal za grzechy: on także jest działaniem wewnętrznym. Jeśli więc grzech na takim forum został popełniony, żal może stać się przyczyną powstania z tej właśnie formy śmierci. Można z tego wnioskować, iż Augustyn dopuszczał w pewnych sytuacjach możliwość odpuszczenia nawet ciężkich grzechów bez pośrednictwa Kościoła, z pominięciem publicznej pukuty.

Podobnie ma się rzecz z grzechem, który został już popełniony na zewnątrz, a którego symbolem jest zmarły syn wdowy z Nain:

„Jeśli natomiast uczynił, co postanowił, nastąiła śmierć, i już jest na zewnątrz; lecz ona się kończy żałowaniem, a umarły wyniesiony, przywrócony jest życiu" ${ }^{\prime 3}$.

Jeśli grzesznik żałuje, także „zostaje wskrzeszony”: żal jest końcem jego duchowej śmierci, oddaje go prawdziwemu życiu.

Zagadnienie to rozwinął szerzej biskup Hippony interpretując perykopę o wskrzeszeniu Łazarza:

„Posłuchaj jeszcze: Chrystus płakał, niech i człowiek płacze. Dlaczego Chrystus płakał? Czyż nie dlatego, aby ludzi płaczu nauczyć. Dlaczego rozrzewnił się i wzruszył siebie? Czyż nie z tego powodu, iż wiara człowie-

${ }^{37}$ Sermo 139a, 2, NBA 31/1, 330: „Sed aliquando respicit Dominus, et paenitet decrevisse, paenitet consensisse; in cubiculo mortuus est, in cubiculo resurgit".

${ }^{38}$ Tamże: „Si autem faciat quod decrevit, processit mors, iam foris est; sed et ipsa paenitendo finitur, et mortuus elatus vitae redditur". 
ka, który słusznie z siebie jest niezadowolony, winna poniekąd się wzruszać przez wyznanie złych czynów, aby mocą pokuty ustąpił nałóg grzeszenia?"39.

W pierwszych dwóch rodzajach grzesznych sytuacji wystarczał sam żal, by mogło nastąpić odpuszczenie grzechu. Nie może się obyć bez niego także i trzecia sytuacja, którą symbolizuje wskrzeszenie Łazarza. Kaznodzieja zwraca uwagę, że w tym zdarzeniu i sam Jezusa się rozrzewnił i zapłakał nad śmiercią przyjaciela. Tym bardziej sam grzesznik powinien zapłakać nad swoim grzechem. Jezus zapłakał, by nauczyć ludzi żalu za grzechy. Człowiek popełniający grzechy, winien być z siebie niezadowolony. Żal powinien jednak człowieka wierzącego doprowadzać do kolejnego elementu postawy, jakim jest wyznanie grzechów:

„Jeśli sobie z grzechu nic nie robisz, leżysz umarły; i jeśli tym wszystkim, co mówiłem gardzisz, leżysz pogrzebany; skoro wyznajesz (swą winę), wychodzisz. Czym jest bowiem wyjście, jeśli nie jakby wyjściem z ukrycia, aby się ukazać" $"$.

Grzechu nie należy jednak bagatelizować, i nie można go lekceważyć. Czyniąc zaś tak, człowiek utwierdza się w nim. Wyznanie swojej winy nie jest obojętnym przejściem obok niej, ale jest ukazaniem jej na zewnątrz, jest jej nazwaniem. Kiedy zaś nastąpią żal i wyznanie, konieczne jest jeszcze jedno - dalsze działanie samego grzesznika. Mówi o nim Biskup Hippony kontynuując swą interpretację:

„On, On, którego głos do serca przenika, woła: «Łazarzu, wyjdź na zewnątrz», to jest: Żyj, wyjdź z grobu, zmień życie, skończ śmierć. I wyszedł ów zmarły, udręczony związaniem; ponieważ, choć zaprzestał grzeszyć, jeszcze do przeszłych rzeczy jest przywiązany, i dziełem koniecznym jest, by błagał i czynił pokutę za te czyny; nie za te, które czyni, ponieważ już nie czyni; ożył, nie czyni, lecz za te, które czynił, którymi jest związany"41.

Ostatnim koniecznym elementem odpuszczenia grzechu jest podjęcie pokuty. Chodziło naszemu Kaznodziei o pokutę za grzechy minione, których

${ }^{39}$ In Joannis Evangelium tractatus 49, 19, CCL 36, 430: „Audi adhuc: flevit Christus, fleat se homo. Quare enim flevit Christus, nisi quia flere hominem docuit? Quare fremuit et turbavit semetipsum, nisi quia fides hominis sibi merito displicentis fremere quodammodo debet in accusatione malorum operum, ut violentiae poenitendi cedat consuetudo peccandi?", PSP 15/2, 43.

${ }^{40}$ Tamże 49, 24, CCL 36, 431: „Quando contemnis, mortuus iaces; et si tanta quanta dixi contemnis, sepultus iaces: quando confiteris, procedis. Quid est enim procedere, nisi ab occultis velut exeundo manifestari?", PSP 15/2, 45.

${ }^{41}$ Sermo 139a, 2, NBA 31/1, 330: „Ille, ille, cuius vox ad cor pervenit, clamet: «Lazare, veni foras»; id est: Vive, exi de sepulchro, muta vitam, fini mortem. Et processit ille mortuus, ligatus institit; quia, etsi desiit peccare, adhuc de praeteritis reus est, et opus est ut precetur, et agat paenitentiam propter facta; non propter ea quae facit, quia iam non facit; reviviscit, non facit; sed propter ea, quae fecit, adhuc ligatus est". 
„zmartwychwstały” już nie popełnia, za które żałował i które wyznał, ale którymi pozostaje jeszcze związany.

Wezwanie skierowane do Łazarza jest zachętą do prawdziwego życia, do opuszczenia grobu grzesznego przyzwyczajenia, do zmiany dotychczasowego postępowania. Jego wyjście $\mathrm{z}$ grobu interpretowane jest jako wyznanie grzechu i przyznanie się do winy. Podobnie, jak w przypadku grzechu wewnętrznego, potrzebne jest do tego uświadomienie sobie winy. Mimo tego pozostaje jednak jeszcze samo przyzwyczajenie, które nadal wiąże człowieka, podobnie jak Łazarz wychodząc z grobu pozostawał związany. Dlatego konieczne jest podjęcie pokuty przez grzesznego człowieka, by w ten sposób uwolnić się, nie tyle już od grzechów, których popełniania zaprzestał, ale od samego przyzwyczajenia, które nadal go wiąże.

3. Rola Kościoła. Interpretując perykopę o wskrzeszeniu młodzieńca z Nain, Augustyn zwrócił uwagę, iż Jezus wskrzeszając zmarłego, oddaje go jego matce. Radość matki-wdowy jest radością Kościoła, który cieszy się z wskrzeszonego duchowo zmarłego syna. Grzesznik, dzięki uzdrawiającej mocy Chrystusa i odpuszczeniu grzechów, przywracany jest matce-Kościołowi i wspólnocie wierzących ${ }^{42}$. Sam Kościół wydaje się jednak w tej sytuacji pozostawać bierny, jakby nie miał wpływu na nawracającego się grzesznika.

W odróżnieniu do opisów wskrzeszeń córki Jaira oraz syna wdowy, przy wskrzeszeniu Łazarza Augustyn dostrzega, że Jezus włącza w dzieło przez siebie dokonywane także swoich uczniów. Czyni to po raz pierwszy, kiedy prosi o to, by odsunęli kamień grobowy:

„«Odsuńcie, rzecze, kamień». Jakże mógłby sprawić, by tamten z martwych powstał, gdyby nie usunął ciężaru przyzwyczajenia? Głośno wołajcie, wiążcie, napominajcie, czyńcie wyrzuty, usuwajcie kamień; gdy to dostrzeżecie, nie chciejcie się powstrzymywać; trudźcie się, lecz usuwajcie kamień" ${ }^{33}$.

Rozkaz Jezusa dotyczy odsunięcia kamienia, który zakrywał grób, bo uniemożliwiał wyjście z niego Łazarzowi. Przez to Kaznodzieja zwraca uwagę, że i złe przyzwyczajenia trzeba odrzucić, oraz odwrócić się od nich. Nie jest to możliwe dla samego grzesznika, ale dokonuje się z pomocą innych. Zachęcając do tego podpowiada, w jaki sposób można to czynić: „Głośne wołanie” to zachęta do modlitwy błagalnej, wytrwałej i ustawicznej, w intencji grzeszni-

${ }^{42}$ Por. Sermo 98, 2, NBA 30/2, 200: „De iuvene illo resuscitato gavisa est mater vidua (por. Lc 7, 12): de hominibus in spiritu quotidie suscitatis gaudet mater Ecclesia”, thum. M. Starowieyski, OŻ 3, Kraków 1984, 181: „Z młodzieńca zmartwychwstałego uradowała się matka wdowa; z ludzi codziennie wskrzeszonych cieszy się matka Kościół”.

${ }^{43}$ Sermo 139a, 2, NBA 31/1, 330: „«Auferte, inquit, lapidem». Unde fieri posset ut ille resurgeret, nisi remoto consuetudinis pondere? Exclamate, ligate, obiurgate, accusate, lapidem removete; quando tales videtis, nolite parcere; laboratis, sed lapidem removetis". 
ka. Często i w podobny sposób Augustyn tę modlitwę określał i rozumia144. Wiązanie, czy raczej obwiązywanie, można utożsamić z formą zabezpieczania przed grzechem lub przed pogłębieniem grzechu. Dotyczy zapewne „związania" rozumianego jako niedopuszczenie do Eucharystii, czyli sakramentu ołtarza $^{45}$. Może to być również forma leczenia samego grzesznika i pomoc w wyzwoleniu się z nałogu. Wreszcie owym usuwaniem kamienia jest napominanie i czynienie wyrzutów grzeszącym, naprowadzanie ich na drogę właściwego postępowania. Słowa te są skierowane nie tyle do samego grzesznika, przyzwyczajonego do grzechu, i być może także nie do końca świadomego swego położenia, ale polecenie „usuńcie kamień” skierowane jest do uczniów Jezusa, a nie do Łazarza, zatem i Kaznodzieja zwraca się do wierzących, nie do samego grzesznika. Biskup Hippony ukazuje tutaj, w przeciwieństwie do poprzednich opisów, rolę osób trzecich - wspólnoty Kościoła, która bierze udział w procesie „wskrzeszania”. Słowa Augustyna: „Gdy to dostrzeżecie, nie chciejcie się powstrzymywać" ${ }^{46}$ miały posłużyć do uświadomienia słuchaczom odpowiedzialności całego Kościoła za losy grzesznika, miały przypomnieć, że upomnienie braterskie, czy napomnienie grzesznika jest obowiązkiem człowieka wierzącego.

$\mathrm{Na}$ napomnieniu grzeszących nie kończy się jednak rola Kościoła. W słowach skierowanych do uczniów, w momencie, gdy wskrzeszony Łazarz wyszedł już z otwartego grobu, Augustyn widzi kolejne zadanie:

„Więc sługom swojego Kościoła, których ręka wyciąga się nad pokutującymi, Chrystus powiedział: «Rozwiążcie go i pozwólcie chodzić». Rozwiążcie, rozwiążcie, «co rozwiążecie na ziemi, będzie rozwiązane i w niebie». Kto to ode mnie usłyszał i przyjął, niech uważa, że czytał, co napisałem; kto zaś nie usłyszał, zapisał w sercu, aby mógł czytać, kiedy zapragnie" ${ }^{\$ 77}$.

Kaznodzieja zwraca uwagę na słowa Chrytusa, który po wyjściu Łazarza z grobu polecił uczniom rozwiązać skrępowanego jeszcze Łazarza. W ten sposób zasugerował, że w tych dwóch elementach zawarta została nauka o roli,

${ }^{44}$ Por. W. Kamczyk, Zagadnienie modlitwy $w$ «Enarrationes in psalmos» św. Augustyna, w: Modlitwa i miłosierdzie w "Enarrationes in psalmos» św. Augustyna, red. A. Uciecha, SACh NS 5, Katowice 2007, 59.

${ }^{45}$ Dotyczyło to tzw. pokutników, czyli czyniących publiczną pokutę. Im Kościół zabraniał przystępowania do stołu eucharystycznego, by w ten sposób nie popełniali świętokradztwa, por. Sermo 352, 3, 8, NBA 34, 218: „Est paenitentia gravior atque luctuosior, in qua proprie vocantur in Ecclesia paenitentes, remoti etiam a Sacramento altaris participandi, ne accipiendo indigne, iudicium sibi manducent et bibant"; zob. W. Roetzer, Des heiligen Augustinus Schriften als liturgiegeschichtliche Quelle. Eine liturgie-geschichtliche Studie, München 1930, 189.

${ }^{46}$ Sermo 139a, 2, NBA 31/1, 330: „Quando tales videtis, nolite parcere".

${ }^{47}$ Sermo 139a, 2, NBA 31/1, 332: „Ergo ministris Ecclesiae suae, per quos manus imponitur paenitentibus, Christus dicit: «Solvite eum, et sinite illum» (J 11, 43-44). Solvite, solvite: «quae solveritis in terra, soluta erunt in caelo» (Mt 18, 18). Qui haec a me audierat et tenebat, putet se modo legisse quod scripsi; qui autem non audierat, in corde scribat, ut quando vult legat". 
jaką powierzył w tym względzie Jezus swoim uczniom, czyli Kościołowi. Na poparcie swej tezy przywołał słowa z Ewangelii według świętego Mateusza: „Co rozwiążecie na ziemi, będzie rozwiązane i w niebie (Mt 18, 18)”. Kościół dla Augustyna jest tym, który dopełnia dzieło Jezusa Chrystusa, jeśli chodzi o kwestię odpuszczenia grzechów i pojednania ${ }^{48}$. Posuwa się nawet do stwierdzenia, że poza Kościołem nikt nie jest w stanie rozwiązać więzów grzechu ${ }^{49}$.

To zadanie, dotyczące „rozwiązywania”, realizuje się w momencie, gdy słudzy Kościoła wyciagają nad pokutującymi ręce. Być może właśnie tak wyglądał w starożytności, w czasach świętego Augustyna, obrzęd publicznego pojednania pokutujących ze wspólnotą Kościoła i Bogiem ${ }^{50}$. Wiązało się to $\mathrm{z}$ dopuszczeniem na nowo takiego chrześcijanina do sakramentu ołtarza. Kwestia tego obrzędu nie została szerzej rozwinięta i opisana w homilii przez Augustyna, była więc zapewne dość oczywista dla słuchaczy. Pojednania pokutujących dokonywano prawdopodobnie dość często, nie było więc potrzeby specjalnego przypominania tego obrzędu w homilii. Ważniejsze było jego uzasadnienie oraz zwrócenie uwagi na to, kogo on dotyczy - stąd też taki cel ma interpretacja Janowej perykopy.

Interpretując perykopę o wskrzeszeniu Łazarza Augustyn posłużył się dla celów duszpasterskich metodą duchowego odkrywania sensu czynów Jezusa. W tym celu najpierw osadził cudowne wydarzenie w kontekście innych wskrzeszeń, by wykazując nie tylko zachodzące pomiędzy nimi podobieństwa, lecz przede wszystkim różnice, w miarę obrazowo i przystępnie przedstawić naukę na temat odpuszczenia grzechów. Odkrywając podobieństwa pomiędzy wskrzeszeniem córki przełożonego synagogi w Kafarnaum, syna wdowy z Nain oraz Łazarza, nasz Kaznodzieja wskazał na osobę uzdrawiającego - Jezusa, który jest tym, który odpuszcza grzechy wraz z Bogiem Ojcem. Podkreślił także oczyszczającą moc żalu za grzechy. Wreszcie związał odpuszczenie grzechu z przywróceniem ,zmarłego” jego bliskim i rodzinie, która w rozumieniu Augustyna jest symbolem wspólnoty wierzących, Kościołem-matką.

Perykopa opisująca wskrzeszenie Łazarza okazała się jednak dla interpretatora o wiele bogatsza, dotyczyła bowiem zmarłego, złożonego od czterech dni w grobie. Perykopa ta stała się więc obrazem tych, którzy w grzechu posu-

${ }^{48}$ Por. Pontet, L'exégèse de S. Augustin, s. 568.

${ }^{49}$ Por. Sermo 295, 3, 2, NBA 33, 312: „Timeant ligati, timeant soluti. Qui soluti sunt, timeant ne ligentur: qui ligati sunt, orent ut solvantur. «Criniculis peccatorum suorum unusquisque constringitur» (Prov. 5, 22): et praeter hanc Ecclesiam nihil solvitur".

${ }^{50}$ Biskup, którego zadaniem byo udzielanie chrztu świętego, był także szafarzem pojednania, to on wyciaggał nad pokutującymi ręce. Augustyn nie sprecyzował, czy obrzęd ten związany był $\mathrm{z}$ konkretnym wydarzeniem $\mathrm{w}$ roku liturgicznym, czy sprawowany był wielokrotnie w ciagu roku, por. Fitzgerald, Pénitence, s. 1121. 
nęli się najdalej, aż do przyzwyczajenia i nałogu. Samo odpuszczenie grzechu i w tym wypadku dokonujące się mocą Jezusa Chrystusa, powinno rozpocząć się od uświadomienia sobie grzechu i jego „drogi”, co ma doprowadzić do żalu za grzechy. Kaznodzieja podkreśla jednak w tym wypadku szczególne działanie łaski, która zostaje „obudzona” przez Jezusa jego wołaniem. W ten sposób także następuje, konieczne dla odpuszczenia grzechów, uświadomienie sobie zła przez samego człowieka, co w konsekwencji prowadzi do żalu za grzechy, który powinien w wypadku grzesznych przyzwyczajeń łączyć się $\mathrm{z}$ wyznaniem winy i pokuta. Wreszcie i w tym wypadku odpuszczenie grzechów nie tylko łączy się z przywróceniem grzesznika wspólnocie wierzących, lecz ukazuje rolę tej wspólnoty w procesie pojednania, co ma odniesienie do praktyki publicznej pokuty i pojednania.

Podjęte zagadnienie Augustynowej interpretacji perykopy o wskrzeszeniu Łazarza zostało przedstawione jedynie w ograniczonym zakresie dotyczącym problematyki odpuszczenia grzechów. Celowo pominięte zostały związki tej perykopy z tematem zmartwychwstania Chrystusa i okresem paschalnym, gdyż zagadnienia te są przedmiotem innej rozprawy ${ }^{51}$. Nierozwinięte pozostały również motywy interpretacji pozostałych perykop, opisujących wskrzeszenia oraz kwestie odmian sytuacji grzechu, opisanych przez Augustyna. Mam nadzieję, iż niniejszy artykuł stanie się inspiracją do podjęcia tematów, dotyczących zagadnień duszpasterskich i teologicznych u św. Augustyna.

\section{THE PERICOPE ABOUT THE RESURRECTION OF LAZARUS (JOHN 11, 1-44) AND TEACHING OF SAINT AUGISTINE ABOUT FORGIVENESS OF SINS}

\section{(Summary)}

Interpreting the pericope about the resurrection of Lazarus, Augustine began his commentary with a reflection about three resurrection miracles described in the Gospels. Namely the raising to life Jairus' daughter, young man of Nain and Lazarus. The latter seems to be the richest in theological meaning. Augustine compared these three dead with three types of $\sin$ (in the heart, in deed and out of habit). Those dead were raised to life by Jesus. He is the one who has the power to do so. The forgiveness of sins is here presented as a spiritual resurrection. However in the most serious situation is Lazarus. It is a picture of the sinner, who not only commits sin, but is subjected to a habit. The forgiveness of sins is done by the power of Christ, but there is also the need for confession of sin, repentance, and the interference of Mother Church, which releases us from the bondage of sin.

${ }^{51}$ Por. W. Kamczyk, Tota Paschalis Solemnitas. Teologia i duszpasterstwo w kazaniach i homiliach św. Augustyna, SACh NS 12, Katowice 2012, 114-116. 
